\title{
STRUCTURAL CHANGES IN LATOSOLS OF THE CERRADO REGION: II - SOIL COMPRESSIVE BEHAVIOR AND MODELING OF ADDITIONAL COMPACTION ${ }^{(1)}$
}

\author{
Eduardo da Costa Severiano ${ }^{(2)}$, Geraldo César de Oliveira ${ }^{(3)}$, Moacir \\ de Souza Dias Júnior ${ }^{(4)}$ Katia Aparecida de Pinho Costa ${ }^{(5)}$, Vinícius \\ de Melo Benites ${ }^{(6)} \&$ Silvio Marcos Ferreira Filho ${ }^{(7)}$
}

\begin{abstract}
SUMMARY
Currently in Brazil, as in other parts of the world, the concern is great with the increase of degraded agricultural soil, which is mostly related to the occurrence of soil compaction. Although soil texture is recognized as a very important component in the soil compressive behaviors, there are few studies that quantify its influence on the structural changes of Latosols in the Brazilian Cerrado region. This study aimed to evaluate structural changes and the compressive behavior of Latosols in Rio Verde, Goiás, through the modeling of additional soil compaction. The study was carried out using five Latosols with very different textures, under different soil compaction levels. Water retention and soil compression curves, and bearing capacity models were determined from undisturbed samples collected on the $B$ horizons. Results indicated that clayey and very clayey Latosols were more susceptible to compression than medium-textured soils. Soil compression curves at density values associate with edaphic functions were used to determine the beneficial pressure $\left(\sigma_{b}\right)$, i.e., pressure with optimal water retention, and critical pressure $\left(\sigma_{\text {crMAC }}\right)$, i.e., pressure with macroporosity below critical levels. These pressure values were higher than the preconsolidation pressure $\left(\sigma_{p}\right)$, and therefore characterized as additional compaction. Based on the compressive behavior of
\end{abstract}

\footnotetext{
(1) Part of Doctorate thesis of first author. Partial funding by Conselho Nacional de Desenvolvimento Científico e Tecnológico (CNPq). Process number 142232/2007-6. Received for publication in August 2010 and approved in February 2011.

(2) Professor, Federal Institute of Education, Science and Technology Goiano, Campus Rio Verde (IFGoiano/Campus Rio Verde), P.O. Box: 66, CEP: 75901-970, Rio Verde, Goiás, Brazil., E-mail: severianoec@yahoo.com.br

(3) Professor, Federal University of Lavras, Department of Soil Science (DCS/UFLA), P.O. Box 3037, CEP 37200-000, Lavras, Minas Gerais, Brazil. E-mail: geraldooliveira@dcs.ufla.br

(4) Professor, DCS/UFLA, E-mail: msouzadj@dcs.ufla.br

(5) Professor, IFGoiano/Campus Rio Verde, E-mail: katiazoo@hotmail.com

(6) Researcher, Embrapa Solos Agricultural Research, CEP 22460-000, Rio de Janeiro, Brazil.

(7) Agronomist, University of Rio Verde, E-mail: silvioagro@gmail.com
} 
these Latosols, it can be concluded that the combined preconsolidation pressure, beneficial pressure and critical pressure allow a better understanding of compression processes of Latosols.

Index terms: preconsolidation pressure, beneficial pressure, critical pressure, degradation of agricultural soils, particle-size-distribution.

\title{
RESUMO: ALTERAÇÕES ESTRUTURAIS DE LATOSSOLOS REPRESEN- TATIVOS DA REGIÃO DO CERRADO: II - COMPORTAMENTO COMPRESSIVO DO SOLO E MODELAGEM DA COMPACTAÇÃO ADICIONAL
}

\begin{abstract}
Atualmente, há grande preocupação com o aumento das áreas agrícolas degradadas, o que, na maioria das vezes, está relacionado com a ocorrência da compactação do solo. Apesar de a composição granulométrica do solo ser reconhecidamente importante no comportamento compressivo deste, há carência de estudos que quantificam a sua influência na dinâmica estrutural dos Latossolos oxídicos da região do Cerrado. O objetivo deste trabalho foi avaliar as alterações estruturais e o comportamento compressivo de Latossolos do município de Rio Verde, GO, por meio da modelagem da compactação adicional do solo. O estudo foi conduzido utilizando-se amostras de cinco Latossolos oxídicos muito contrastantes quanto à textura, sob diferentes condições de compactação do solo. Determinaram-se, a partir de amostras indeformadas coletadas no horizonte $B_{w}$ dos solos, as curvas de retenção de água e de compressão do solo, bem como os modelos de capacidade de suporte de carga do solo. Os resultados indicaram que os Latossolos argilosos e muito argilosos estudados, comparativamente aos de textura média, apresentaram elevada suscetibilidade à compactação. As avaliações das curvas de compressão do solo, associadas a valores de densidade do solo de referência relacionados às funções edáficas do solo, permitem a determinação da pressão benéfica $\left(\sigma_{b}\right)$ em termos de retenção de água e da pressão crítica $\left(\sigma_{c r M A C}\right)$ capaz de promover a redução da macroporosidade em níveis considerados críticos para o desempenho das funções edáficas do solo. Por sua vez, essas pressões são superiores à pressão de preconsolidação $\left(\sigma_{p}\right) e$, portanto, caracterizadas como compactação adicional dos Latossolos estudados. Com base no estudo de comportamento compressivo dos Latossolos, é possível concluir que o uso conjunto dos índices - pressão de preconsolidação, pressão benéfica e pressão crítica-permite melhor entendimento do processo de compactação dos Latossolos oxídicos.
\end{abstract}

Termos de indexação: pressão de preconsolidação, pressão benéfica, pressão crítica, degradação do solo, distribuição de partículas por tamanho.

\section{INTRODUCTION}

The degradation of agricultural areas has become a worldwide concern and is related to the dissemination of soil compaction caused by the movement of machinery and equipment in most cases (Canillas \& Salokhe, 2002).

In the region of the Brazilian Cerrado, the development of agriculture has become increasingly based on production technologies depending on the use of agricultural machinery in every stage of the agricultural process. Due to the climate of this region, which allows up to two annual crops, the periods for crop handling are increasingly shortened. Because of the constant increases in size and power of the machinery, which perform large-scale operations and at increasingly lower operating costs, the physical problems of soil tend to aggravate (Yavuzcan et al., 2005). Therefore, studies focused on the identification, critical limits and mitigation of structural changes caused by inadequate soil management must be conducted.

The Latosols of this region have a wide variety of textures with clay contents varying from $150 \mathrm{~g} \mathrm{~kg}^{-1}$ (Embrapa, 2006) to $>750 \mathrm{~g} \mathrm{~kg}^{-1}$ (Gontijo et al., 2008). These soils, which are already highly susceptible to compaction under natural conditions (Ajayi et al., 2009), become even more vulnerable due to the intensity of machinery traffic during the rainy season. Therefore, increased soil water contents (Kondo \& Dias Junior, 1999; Silva et al., 2003; Cardoso, 2007; Cavalieri et al., 2009; Severiano et al., 2010) permit additional compaction by the machinery traffic that is part of the production process. 
Evaluations of soil structural changes must be related to the best conditions for satisfactory yields without affecting the water infiltration capacity of soil and underground water recharge, minimizing soil and nutrient losses by erosion and the silting of waterways (Izidorio et al., 2005). Therefore, for further elucidation of the deleterious impact of inadequate soil use, studies should be carried out that associate the soil quality for plant growth with the soil bearing capacity (Imhoff et al., 2001), besides investigating the ecological role of soil in this scenario.

In this context, the characterization of the soil compressive behavior is essential in the process to prevent the degradation of agricultural areas. For this purpose, the soil compression curve (graphical representation of the relationship between the pressure applied to soil and a characteristic related to soil structure, such as bulk density or void ratio) has been used. The preconsolidation pressure $\left(\sigma_{\mathrm{p}}\right)$, measured in uniaxial compression tests, is considered an indicator of soil compressibility. Loads that exceed the $\sigma_{p}$ value leads to additional soil compaction (Dias Junior, 1994).

Although the mechanical properties of soil provide an estimate of the bearing capacity, there are only few studies in Brazil that quantify the pressure levels that can be applied to avoid critical soil compaction (Oliveira et al., 2003). Therefore, the use of a compression curve will not only determine the pressure levels directly, associated with restrictive structural indices for plant growth and soil hydrological functions, but also provide the values considered beneficial, once the occurrence of additional compaction is not always detrimental to soil quality (Severiano et al., 2011).

Although the granulometric composition of soil is important for the soil compressive behavior, there is a lack of studies that quantify the influence of granulometric soil composition on the structural dynamic of these soils. The objective of this study was to evaluate the structural changes of Latosols by evaluating the compressive behavior and modeling additional soil compaction.

\section{MATERIALS AND METHODS}

The study was conducted with soil samples from Latosol areas (Embrapa, 2006) with different textures (Figure 1), located in the county of Rio Verde, in a microregion in Southeastern Goiás, which has a native vegetation of woods and Atlantic semideciduous forest. The local climate is Aw (Tropical savanna) with a dry Winter and rainy Summer, and the annual average rainfall is between 1,500 and $2,000 \mathrm{~mm}$. The description of the study areas, profile classification, sampling method and analytical procedures for soil chemical and physical characterization were previously described by Severiano et al. (2011).

Soil samples were collected from the $\mathrm{B}_{\mathrm{w}}$ horizon from the 0.8-1.0 $\mathrm{m}$ layer. Using an Uhland sampler, 20 undisturbed samples were randomly collected from each trench, and the samples were filled into $\mathrm{Al}$ rings (volume $80 \mathrm{~cm}^{3}$ ). The samples were coated with PVC film and paraffin for preservation until the moment of hydrophysical analyses.

To determine the soil water retention curves (WRCs), four samples from each Latosol were initially saturated by capillary action with distilled water and balanced by drying. The following soil water tensions $\left(\Psi_{\mathrm{m}}\right)$ were used: $1,2,4,6,8$ and $10 \mathrm{kPa}$ in porous plate funnels; and 33, 60, 100, 500, and $1500 \mathrm{kPa}$ in Richards chambers (Embrapa, 1997).

The remaining samples $(n=16$; samples from each soil) were subjected to the uniaxial compression test according to Dias Junior (1994). The samples were initially saturated by capillary action and balanced at each of the following soil water tensions $\left(\Psi_{\mathrm{m}}\right): 2,6$, 33 , and $1,500 \mathrm{kPa}$ (4 samples per tension). The samples were subsequently subjected to pressures of $25,50,100,200,400,800$, and 1,600 kPa. Pressures were applied to obtain $90 \%$ maximum distortion (Taylor, 1948); the pressure steps were successively applied without releasing the previously applied pressure. After determining soil water retention and compressibility, the samples were oven-dried at $105^{\circ} \mathrm{C}$ for $48 \mathrm{~h}$ to determine the soil water content and bulk density (Bd).

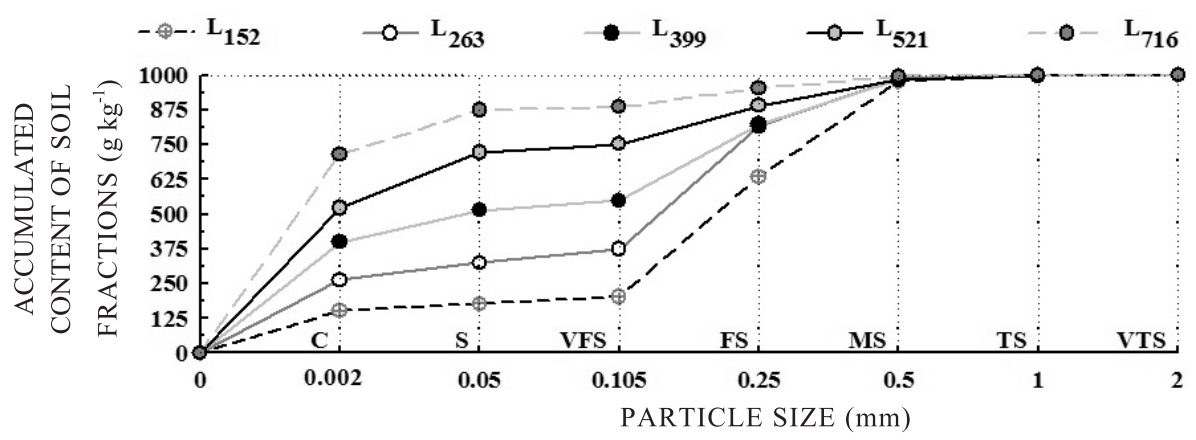

Figure 1. Particle-size-distribution of Latosols (L) in the county of Rio Verde, GO. The subscript number of Latosols indicates the respective clay content $\left(\mathrm{g} \mathrm{kg}^{-1}\right)$. Abbreviations: C: clay; S: silt; VFS: very fine sand; FS: fine sand; MS: medium sand; TS: thick sand; and VTS: very thick sand. 
The volumetric water contents $(\theta)$ were adjusted according to $\Psi_{\mathrm{m}}$, to obtain the WRC following the model proposed by van Genuchten (1980) by the following equation:

$$
\theta=\theta \mathrm{r}+\left\{\theta \mathrm{s}-\theta \mathrm{r} /\left[1+\left(\alpha \Psi_{\mathrm{m}}\right)^{\mathrm{n}}\right]^{\mathrm{m}_{\mathrm{m}}}\right\}
$$

where $\theta$ s and $\theta$ r are the saturation and residual water contents, respectively; and $\alpha, \mathrm{n}$ and $\mathrm{m}$ represent empirical parameters for the fitted model.

The preconsolidation pressure $\left(\sigma_{p}\right)$ and bulk density at preconsolidation pressure (Bdøp) were obtained from the soil compression curve according to Dias Junior \& Pierce (1995). A free flow chart was used to determine the parameters of the soil compression curve. The values for the pressures $(\sigma)$ applied to the samples, corresponding to the compaction levels that were beneficial and critical to the soil functions, were determined for various soil compaction states, using the previously determined reference values of $\mathrm{Bd}$ (Severiano et al., 2011).

For this purpose, a modification was proposed to the chart used to calculate preconsolidation pressure. Assuming that these pressure levels were located on the virgin compression curve, a linear regression between the logarithm of the pressure applied $(\log \sigma)$ and bulk density $(\mathrm{Bd})$ corresponding to the extension of the virgin compression line was fitted for each sample as shown by the following equations:

$$
B d=a+b(\log \sigma)
$$

where $a$ and $b$ represent empirical parameters of the fitted model.

Therefore, the $\log \sigma$ value was calculated as follows:

$$
\log \sigma=\frac{(B d-a)}{b}
$$

Consequently, the value of $\sigma$ corresponding to additional compaction was calculated as follows:

$$
\sigma=10^{\left[\frac{(B d-a)}{b}\right]}
$$

These calculations were then incorporated into the method proposed by Dias Junior \& Pierce (1995). The free flow chart with the changes mentioned above is shown in figure 2.

The pressure values $(\sigma)$ obtained in the uniaxial compression test were adjusted for soil water tension $\left(\Psi_{\mathrm{m}}\right)$, thus providing the bearing capacity models for the following pressures: preconsolidation pressure $\left(\sigma_{\mathrm{p}}\right)$, which is characterized as the maximum pressure that

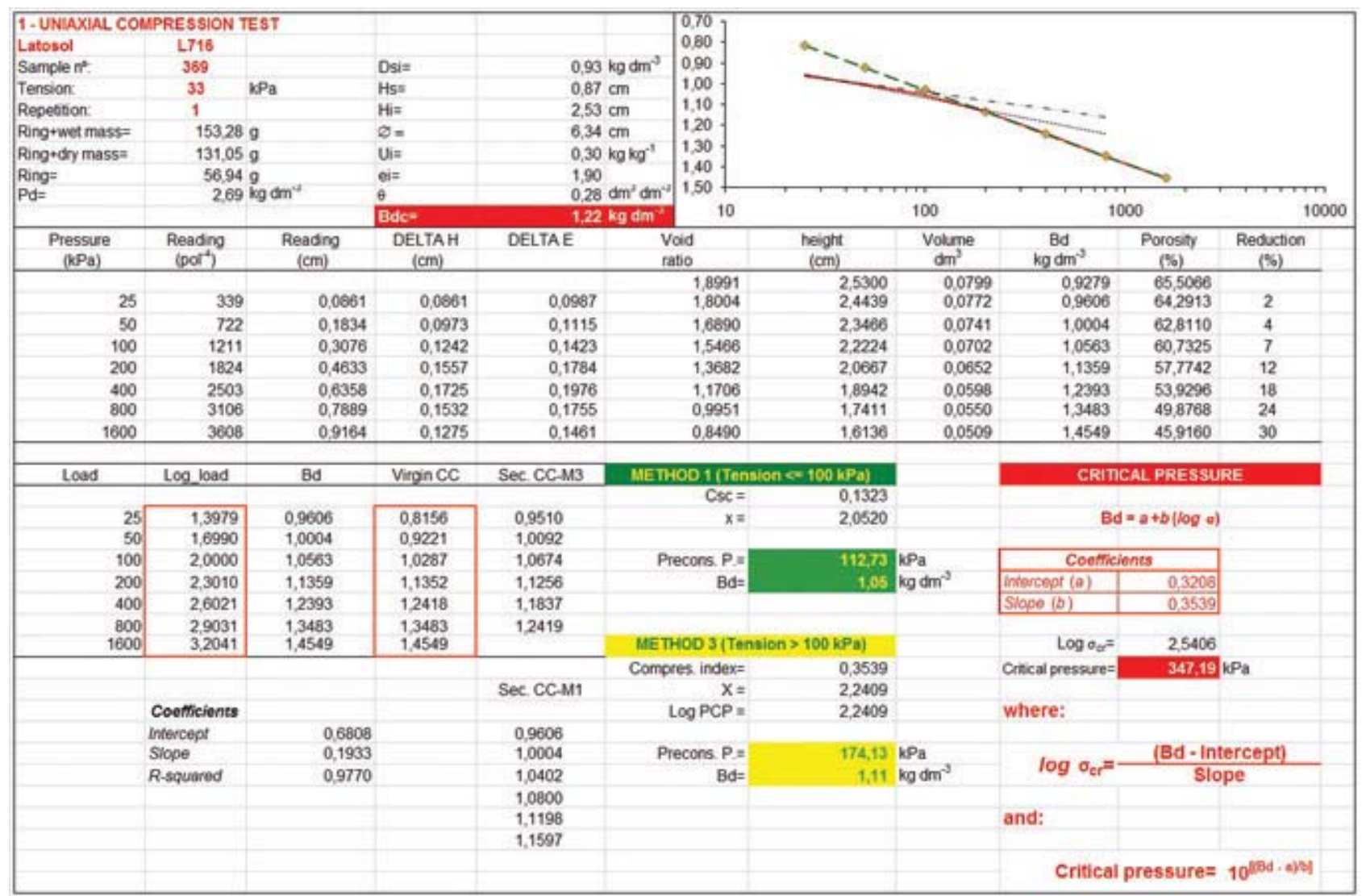

Figure 2. Free flow chart used to estimate preconsolidation pressure, beneficial pressure and critical pressure. 
can be applied to soil to avoid additional soil compaction; beneficial pressure $\left(\sigma_{\mathrm{b}}\right)$ by increasing soil water retention; and critical pressure ( $\sigma \mathrm{cMAC})$, reducing macroporosity to $0.10 \mathrm{dm}^{3} \mathrm{dm}^{-3}$, in contrast to the pressure needed to zero the least limiting water range $(L L W R=0)$, as suggested by Imhoff et al. (2001), because the drainable porosity may already be affected in this case (Severiano et al., 2011). The following equation was used to calculate $\sigma$ as a function of $\Psi_{\mathrm{m}}$ :

$$
\sigma=a \Psi_{\mathrm{m}}^{\mathrm{b}}
$$

or alternatively, the following linear equation was also used to calculate $\sigma$ :

$$
\log \sigma=\log a+b \log \Psi_{\mathrm{m}}
$$

The regression analyses were adjusted using Sigma Plot 10.0 software (Jandel Scientific). In the above equations, the parameters $a$ and $b$ represent the empirical adjustment parameters of the model. The comparisons between the equations estimated for Latosols were performed according to Snedecor \& Cochran (1989). The comparisons tested the data homogeneity (F) and significance of the angular (b) and linear $(\log a)$ coefficients of the linearized equations (Equação 6).

\section{RESULTS AND DISCUSSION}

The water retention (Figure 3) increased proportionately to the increase in clay content for the entire curve. This relationship was due to the increase of textural pores, which are related to this particle size fraction. According to Silva et al. (2008), the total clay content is the main characteristic related to water retention in highly weathered Latosols due to the low organic matter content and a predominance of lowactivity minerals in these soils.
In evaluations of structural soil changes bulk density has been a widely studied property (Severiano et al., 2011). However, to diagnose the occurrence of additional compaction using this characteristic, bulk density data must be interpreted using a soil compression curve (Dias Junior, 1994). Under these conditions, studies showed an increase in the $\mathrm{Bd}$ values at preconsolidation pressure $(\mathrm{Bd} \sigma \mathrm{p})$ of approximately 10 \% (Kondo \& Dias Junior, 1999). Based on these considerations, table 1 shows that the density $(\mathrm{Bd})$ values were greater than the $\mathrm{Bd} \sigma \mathrm{p}$ values in the studied Latosols at maximum water retention (beneficial compaction) and when macroporosity was reduced to $0.10 \mathrm{dm}^{3} \mathrm{dm}^{-3}\left(\mathrm{Bdc}_{\mathrm{MAC}}\right)$. These values corresponded to increases in regions of plastic deformations of the soil compression curve, characterizing additional soil compaction.

The evaluation of soil structural changes based on these reference values (Table 1) allows a quantification of the risks of exposure of agricultural crops to soil physical stresses and to limiting edaphic functions. Furthermore, the compression curve allowed the determination of bulk density according to the applied pressure (Oliveira et al., 2003). Therefore, it was possible to infer the soil pressure levels required to increase the compaction degree to beneficial or even critical values (Figure 4). The pressure levels corresponding to additional compaction (beneficial and critical) were located in the region of non-recoverable deformation even though they were not considered restrictive as discussed above. The $\sigma_{\mathrm{b}}$ and $\sigma_{\mathrm{cMAC}}$ values were determined using equations 2,3 and 4 .

For the structural conditions corresponding to the bulk density in which $L L W R=0$, the drainable porosity of the studied Latosols may already have been affected (Severiano et al., 2011). Therefore, the critical compression was only modeled for the $\mathrm{Bdc}$ MAC values due to the importance of maintaining the environmental functions of soil in the landscape.

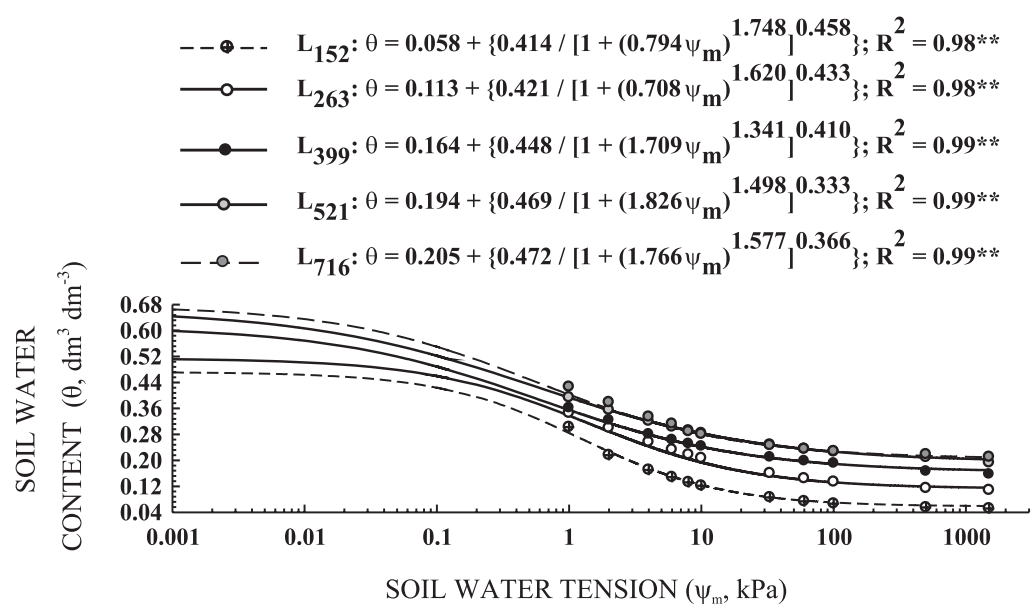

Figure 3. Typical water curve [water content in soil $(\theta)$ as a function of water tension in soil ( $\left.\Psi_{\mathrm{m}}\right)$ ] of Latosols (L) in the county of Rio Verde, GO. Subscript numbers of Latosols correspond to the respective clay content $\left(\mathrm{g} \mathrm{kg}^{-1}\right)$. 
Table 1. Initial bulk density (Bdi) and bulk density at preconsolidation pressure (Bdop) corresponding to beneficial compaction in terms of water retention ( $\mathrm{Bdb}$ ) and the reduction of macroporosity to $0.10 \mathrm{dm}^{3} \mathrm{dm}^{-3}$ $\left(\right.$ Bdc $\left._{\text {MAC }}\right)$ of Latosols $(L)$ in the county of Rio Verde, GO $^{(1)}$

\begin{tabular}{ccccc}
\hline Latosol & Bdi & Bdop & Bdb & Bdc $_{\text {MAC }}$ \\
\hline & \multicolumn{4}{c}{ kg dm$^{-3}$} \\
\cline { 2 - 5 } L $_{152}$ & 1.33 & 1.45 & 1.54 & 1.74 \\
$\mathrm{~L}_{263}$ & 1.22 & 1.34 & 1.45 & 1.59 \\
$\mathrm{~L}_{399}$ & 1.08 & 1.19 & 1.34 & 1.47 \\
$\mathrm{~L}_{521}$ & 0.99 & 1.13 & 1.24 & 1.37 \\
$\mathrm{~L}_{716}$ & 0.83 & 0.97 & 1.08 & 1.22 \\
\hline
\end{tabular}

(1) According to the criteria defined by Severiano et al. (2011). Bdi represents the initial bulk density before compression. Subscript numbers in the Latosol column corresponds to the respective clay content $\left(\mathrm{g} \mathrm{kg}^{-1}\right)$.

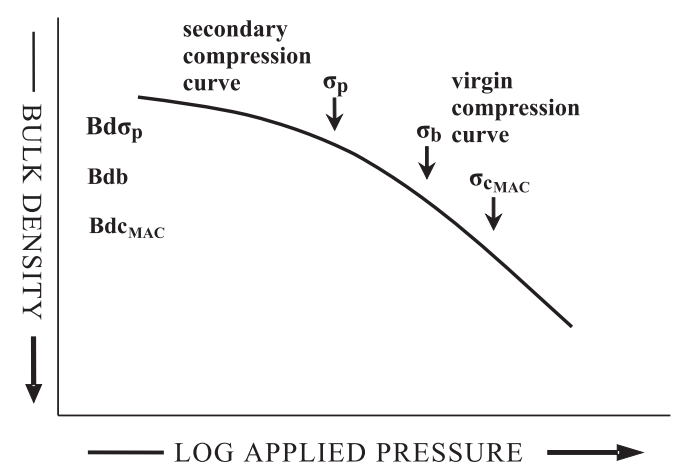

Figure 4. Soil compression curve [variation of bulk density (Bd) as a function of the logarithm of applied pressure $(\sigma)]$ indicating the points corresponding to preconsolidation pressure $\left(\sigma_{p}\right)$, beneficial pressure in terms of water retention $\left(\sigma_{b}\right)$ and critical pressure with reduction of macroporosity to $0.10 \mathrm{dm}^{3} \mathrm{dm}^{-3}\left(\sigma_{\text {cMAC }}\right)$ and the corresponding soil densities. Source: Modified from Dias Junior (1994).

The bearing capacity models of samples of different Latosols based on additional compaction $\left(\sigma_{\mathrm{p}}\right)$, which is beneficial in terms of water retention $\left(\sigma_{\mathrm{b}}\right)$ and critical for the reduction of soil macroporosity to $0.10 \mathrm{dm}^{3} \mathrm{dm}^{-3}$ $\left(\sigma_{\text {cMAC }}\right)$, are shown in figure 5 . The equations representing the various soil compression states were treated separately because there were significant statistical differences among the regressions according to the statistical procedures previously described by Snedecor \& Cochran (1989).

In the present study, the soil bearing capacity decreased as the clay content increased, which resulted from the integrated effect of macroporosity (Severiano et al., 2011) and water retention increases (Figure 2). Macroporosity and water retention are considered crucial in the soil compressive behavior, since they regulate the magnitude with which the soil matrix resist deformation under compression (Oliveira et al., 2003; Severiano et al., 2010).

This behavior may be considered specific for the order of oxidic Latosols due the type of pedological soil structure. In terms of the soil compressive behavior, the mechanical resistance of a soil with granular structure is lower than of other structure types, due to the reduced contact between soil particles (Ajayi et al., 2009). In soils of other classes in other regions of Brazil, the relationship between clay content and preconsolidation pressure is mostly direct under the different systems of use and management (Imhoff et al., 2004; Suzuki et al., 2008) suggesting that the initial state of compression has a greater influence on the compressibility of soils than the lubricating action of water in these soils.

Considering the characteristics of the agricultural machinery used in Brazil (Cardoso, 2007) in addition to the traffic concentrated in the rainy season (Silva et al., 2003; Cavalieri et al., 2009; Severiano et al., 2010), the resistance of these Latosols to additional compression (bearing capacity models based on preconsolidation pressure) was considered very low in these conditions, which should result in some additional compression when subjected to the same agricultural management operations (Figure 5). In clayey and very clayey Latosols, additional compression may occur even when driven on under dry soil conditions (that is, high water tension in soil). Therefore, preventive measures are required to prevent the structural degradation from limiting soil functions.

On the other hand, the greater mechanical resistance observed for the beneficial compaction of Latosols at preconsolidation pressure (Figure 5) was due to the higher soil compaction under these structural conditions (Table 1 and Figure 4). This additional compaction may increase the amount of water available to plants (Severiano et al., 2011) and may be beneficial in terms of the trafficability of the oxidic Latosols in the Cerrado region because this increase in soil bearing capacity may enable the performance of mechanized operations without structural degradation, especially in medium texture Latosols ( $\mathrm{L}_{152}$ and $\left.\mathrm{L}_{263}\right)$. This avoidance of structural degradation is due to the increased friction forces and the number of contact points between particles and, consequently, the lower movement ability of particles. Under these conditions, the greater difficulty of soil deformation causes increased resistance to soil compaction (Imhoff et al., 2001).

In contrast, taking into account the characteristics of the machines used in Brazil (Cardoso, 2007), the mechanical resistance of the clayey and very clayey Latosols under these conditions was still considered low, particularly at low water tension (Figure 5). The small textural variations in the soil profiles, in addition to the similarity of bulk density values observed between the surface layer and the 80 -cm layer 


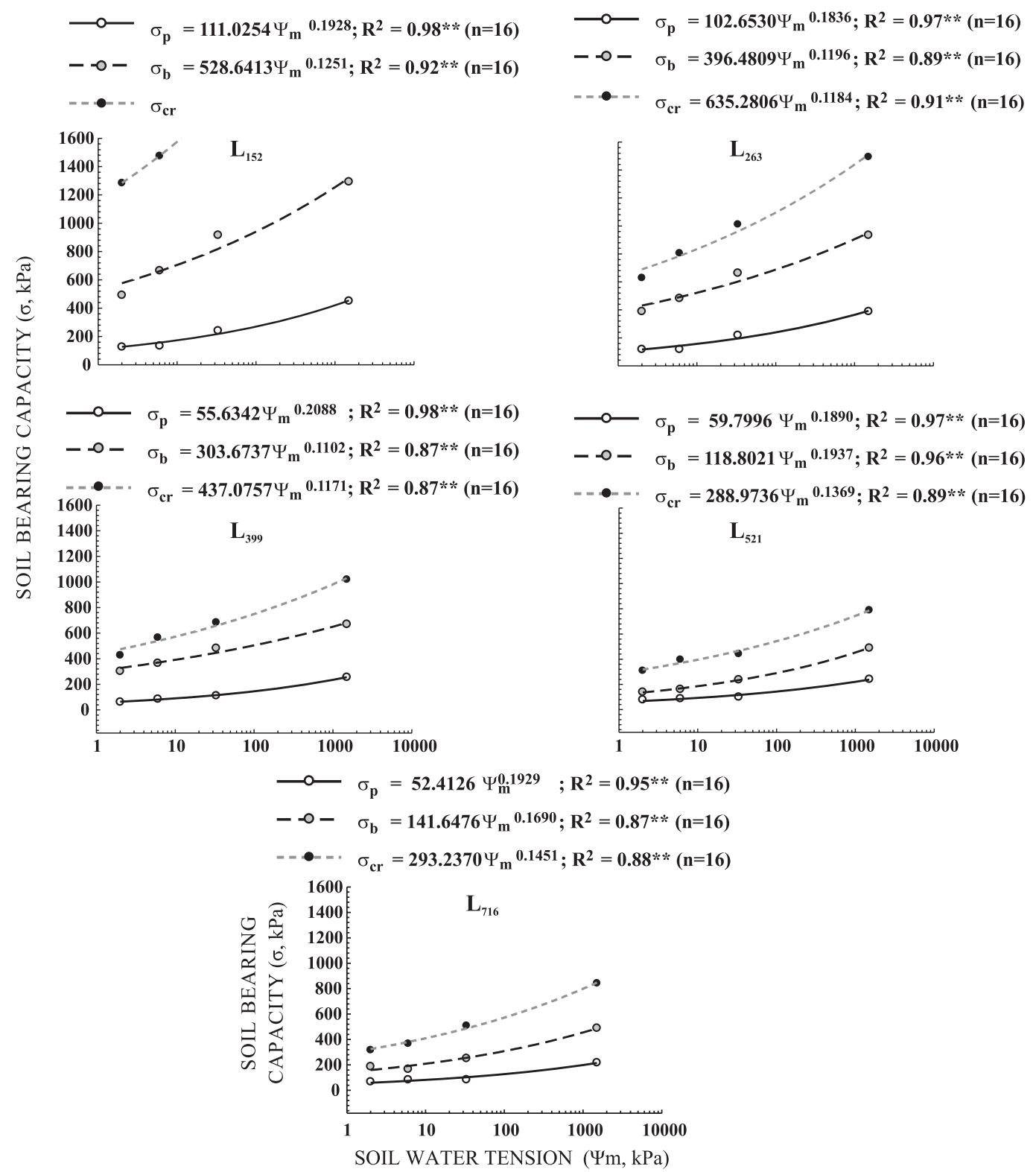

Figure 5. Soil bearing capacity models for additional compaction $\left(\sigma_{\mathrm{p}}\right)$, which is beneficial in terms of water retention $\left(\sigma_{\mathrm{b}}\right)$ and critical for the reduction of soil macroporosity to $0.10 \mathrm{dm}^{3} \mathrm{dm}^{-3}\left(\sigma_{\mathrm{cr}}\right)$, for Latosols $(\mathrm{L})$ in the county of Rio Verde, GO.

( $\mathrm{B}_{\mathrm{w}}$ horizon), indicated a greater possibility for the occurrence of some degree of structural soil degradation by machinery traffic, which would affect the availability of water and oxygen in appropriate quantities for the full development of plants.

Assuming that additional compaction may occur even at beneficial pressure values $\left(\sigma_{\mathrm{b}}\right)$, it is necessary to define limits, within which structural changes do not restrict the edaphic functions related to plant production and underground water recharge, for the planning of mechanized operations. When the pressure levels applied to soil were used for the reduction of macroporosity to $0.10 \mathrm{dm}^{3} \mathrm{dm}^{-3}\left(\sigma_{\mathrm{cMAC}}\right)$, the increase in bearing capacity of medium texture
Latosols made the soils practically resistant to critical compaction in cultivated areas (Figure 5). Importantly, it was not possible to adjust the regression that described the resistance of $\mathrm{L}_{152}$ because $\mathrm{L}_{152}$ had the lowest soil water content values $\left(\Psi_{\mathrm{m}}<6 \mathrm{kPa}\right)$ and presented values that were found in the load range evaluated. Therefore, it was necessary to apply a load of $>1,600 \mathrm{kPa}$ to the drier soil to achieve the above reduction in macroporosity.

Similar results have been indirectly confirmed by analyses of the relationship between soil mass and soil volume in soils with thick texture (Abreu et al., 2004; Carneiro et al., 2009; Sales et al., 2010), which is usually associated with adequacy for machinery 
traffic or the pressure of grazing animals in the cited studies. In this context, the evaluation of structural changes based on the compressive behavior under limiting conditions demonstrates the relevance of the resistance of the soil matrix to deformation to understand the compaction process of these soils.

For the clayey and very clayey Latosols, the bearing capacity for critical compaction indicated that structural degradation may occur, particularly at low soil water tension (Figure 5). These results were similar to those found by Oliveira et al. (2003) and necessary to promote the reduction of soil porosity to levels considered critical for the majority of crops grown, on red Latosol with clayey texture (530 $\left.\mathrm{g} \mathrm{kg}^{-1}\right)$ in the Cerrado region. Thus, the mechanization of cultural treatments must be introduced with caution to avoid soil structural degradation, especially when considering that the destruction of macropores can occur during the first machinery passes (Horn et al., 1995).

A substantial change in the soil hydrological properties has to be expected when soils are subjected to agricultural use, regardless of defined critical limits to anthropogenic activities. Therefore, coordinated global planning effort is required to find management strategies that maximize production and minimize the environmental impact (Lal, 1993; Severiano et al., 2011).

In compensation for the reduction of macroporosity to obtain agricultural and environmental sustainability in the Cerrado region agricultural systems should be adopted that break up slopes with agricultural terraces, use minimal soil tillage and plant species that can break compacted layers and form biopores that favor preferential water flow in soil in crop rotation systems (Abreu et al., 2004; Jimenez et al., 2008), must be considered.

\section{CONCLUSIONS}

1. The clayey and very clayey oxidic Latosols have a lower bearing capacity than those with medium texture.

2. The evaluation of soil compression curves associated with reference bulk density values and related to the edaphic functions allowed the determination of beneficial pressure (in terms of water retention) and critical pressure (reducing macroporosity to levels that are considered critical for the performance of edaphic functions).

3. The combined use of preconsolidation pressure, beneficial pressure and critical pressure allowed a better understanding of additional compaction and harmful compaction in oxidic Latosols.

\section{LITERATURE CITED}

ABREU, S.L.; REICHERT, J.M. \& REINERT, D.J. Escarificação mecânica e biológica para a redução da compactação em argissolo franco-arenoso sob plantio direto. R. Bras. Ci. Solo, 28:519-531, 2004.

AJAYI, A.E.; DIAS JUNIOR, M.S.; CURI, N.; GONTIJO, I.; ARAUJO JUNIOR, C.F. \& INDA JUNIOR, A.V. Relation of strength and mineralogical attributes in Brazilian Latosols. Soil Tillage Res., 102:14-18, 2009.

CANILLAS, E.C. \& SALOKHE, V.M. A decision support system for compaction assessment in agricultural soils. Soil Tillage Res., 65:221-230, 2002.

CARDOSO, V.M.F. Sustentabilidade estrutural de um solo na região do Alto Paranapanema/SP, submetido a dois sistemas de cultivo. Botucatu, Universidade Estadual Paulista, 2007. 121p. (Tese de Doutorado)

CARNEIRO, M.A.C.; SOUZA, E.D.; REIS, E.F.; PEREIRA, H.S. \& AZEVEDO, W.R. Atributos físicos, químicos e biológicos de solo de Cerrado sob diferentes sistemas de uso e manejo. R. Bras. Ci. Solo, 33:147-157, 2009.

CAVALIERI, K.M.V.; SILVA, A.P.; TORMENA, C.A.; LEÃO, T.P.; DEXTER, A.R. \& HÅKANSSON, I. Long-term effects of no-tillage on dynamic soil physical properties in a Rhodic Ferrasol in Paraná, Brazil. Soil Tillage Res., 103:158-164, 2009 .

DIAS JUNIOR, M.S. Compression of three soils under longterm tillage and wheel traffic. East Lansing, Michigan State University, 1994. 114p. (Tese de Doutorado)

DIAS JUNIOR, M.S. \& PIERCE, F.J. A simple procedure for estimating preconsolidation pressure from soil compression curves. Soil Technol., 8:139-151, 1995.

EMPRESA BRASILEIRA DE PESQUISA AGROPECUÁRIA EMBRAPA. Centro Nacional de Pesquisas de Solos. Manual de métodos de análises de solo. 2.ed. Brasília, Produção de Informação, 1997. 212p.

EMPRESA BRASILEIRA DE PESQUISA AGROPECUÁRIA EMBRAPA. Centro Nacional de Pesquisa de Solos. Sistema brasileiro de classificação de solos. 2.ed. Brasília, Produção de Informação, 2006. 306p.

GONTIJO, I.; DIAS JUNIOR, M.S.; GUIMARÃES, P.T.G. \& ARAUJO JUNIOR, C.F. Atributos físico-hídricos de um Latossolo de Cerrado em diferentes posições de amostragem na lavoura cafeeira. R. Bras. Ci. Solo, 32:22272234,2008 .

HORN, R.; DOMZAL, H.; SLOWIŃSKA-JURKIEWICZ, A. \& OUWERKERK, C.van. Soil compaction processes and their effects on the structure of arable soils and the environment. Soil Tillage Res., 35:23-36, 1995.

IMHOFF, S.; SILVA, A.P.; DIAS JUNIOR, M.S. \& TORMENA, C.A. Quantificação de pressões críticas para o crescimento das plantas. R. Bras. Ci. Solo, 25:11-18, 2001. 
IMHOFF, S.; SILVA, A.P. \& FALLOW, D. Susceptibility to compaction, load support capacity, and soil compressibility of Hapludox. Soil Sci. Soc. Am. J., 68:17-24, 2004.

IZIDORIO, R.; MARTINS FILHO, M.V.; MARQUES JUNIOR, J.; SOUZA, Z.M. \& PEREIRA, G.T. Perdas de nutrientes por erosão e sua distribuição espacial em área sob canade-açúcar. Eng. Agríc., 25:660-670, 2005.

JIMENEZ, R.L.; GONÇALVES, W.G.; ARAÚJO FILHO, J.V.; ASSIS, R.L.; PIRES, F.R. \& SILVA, G.P. Crescimento de plantas de cobertura sob diferentes níveis de compactação em um Latossolo Vermelho. R. Bras. Eng. Agríc. Amb., 12:116-121, 2008.

KONDO, M.K. \& DIAS JUNIOR, M.S. Compressibilidade de três Latossolos em função da umidade e uso. R. Bras. Ci. Solo, 23:211-218, 1999.

LAL, R. Tillage effects on soil degradation, soil resilience, soil quality, and sustainability. Soil Tillage Res., 27:1-8, 1993.

OLIVEIRA, G.C.; DIAS JUNIOR, M.S.; RESCK, D.V.S. \& CURI, N. Compressibilidade de um Latossolo Vermelho argiloso de acordo com a tensão de água no solo, uso e manejo. R. Bras. Ci. Solo, 27:773-781, 2003.

SALES, L.E.O.; CARNEIRO, M.A.C.; SEVERIANO, E.C.; OLIVEIRA, G.C. \& FERREIRA, M.M. Qualidade física de Neossolo Quartzarênico submetido a diferentes sistemas de uso agrícola. Ci. Agrotec., 34:667-674, 2010.

SEVERIANO, E.C.; OLIVEIRA, G.C.; DIAS JÙNIOR, M.S.; COSTA, K.A.P.; CASTRO, M.B. \& MAGALHÃES, E.N. Potencial de descompactação de um Argissolo promovido pelo capim-tifton 85. R. Bras. Eng. Agríc. Amb., 14:39-45, 2010.
SEVERIANO, E.C.; OLIVEIRA, G.C.; DIAS JÚNIOR, M.S.; COSTA K.A.P.; SILVA, F.G. \& FERREIRA FILHO, S.M. Structural changes in Latosols representative of the Cerrado Region: I - Relationships between soil physical attributes and least limiting water range. R. Bras. Ci. Solo, 35:773-782, 2011.

SILVA, A.P.; TORMENA, C.A.; FIDALSKI, J. \& IMHOFF, S. Funções de pedotransferência para as curvas de retenção de água e de resistência do solo à penetração. R. Bras. Ci. Solo, 32:1-10, 2008.

SILVA, R.B.; DIAS JUNIOR, M.S.; SILVA, F.A.M. \& FOLE, S.M. O tráfego de máquinas agrícolas e as propriedades físicas, hídricas e mecânicas de um Latossolo dos Cerrados. R. Bras. Ci. Solo, 27:973-983, 2003.

SNEDECOR, G.W. \& COCHRAN, W.G. Statistical methods. 8.ed. Ames, Iowa State University, 1989. 503p.

SUZUKI, L.E.A.S.; REINERT, D.J.; REICHERT, J.M. \& LIMA, C.L.R. Estimativa da susceptibilidade à compactação e do suporte de carga do solo com base em propriedades físicas de solos do Rio Grande do Sul. R. Bras. Ci. Solo, 32:963973, 2008 .

van GENUCHTEN, M.T. A closed-form equation for predicting the hydraulic conductivity of unsaturated soils. Soil Sci. Soc. Am. J., 44:892-898, 1980.

TAYLOR, D.W. Fundamentals of soil mechanics. New York, J. Wiley, 1948. 700p.

YAVUZCAN, H.G.; MATTHIES, D. \& AUERNHAMMER, H. Vulnerability of Bavarian silty loam soil to compaction under heavy wheel traffic: Impacts of tillage method and soil water content. Soil Tillage Res., 84:200-215, 2005. 